\title{
Influence of peptides and amino acids on fermentation rate and de novo synthesis of amino acids by mixed micro-organisms from the sheep rumen
}

\author{
Cengiz Atasoglu, Carmen Valdés*, C. James Newbold and R. John Wallace $\dagger$ \\ Rowett Research Institute, Bucksburn, Aberdeen AB21 9SB, UK
}

(Received 7 June 1998 - Revised 21 September 1998 - Accepted 17 November 1998)

\begin{abstract}
The influence of different $\mathrm{N}$ sources on fermentation rate and de novo amino acid synthesis by rumen micro-organisms was investigated in vitro using rumen fluid taken from four sheep receiving a mixed diet comprising $(\mathrm{g} / \mathrm{kg} \mathrm{DM})$ : grass hay 500 , barley $299 \cdot 5$, molasses 100 , fish meal 91, minerals and vitamins 9.5. Pancreatic casein hydrolysate (P; comprising mainly peptides with some free amino acids; $10 \mathrm{~g} / \mathrm{l}$ ), free amino acids (AA; casein acid hydrolysate + added cysteine and tryptophan; $10 \mathrm{~g} / \mathrm{l})$, or a mixture of L-proline, glycine, L-valine and L-threonine (M; $0.83 \mathrm{~g} / \mathrm{l}$ each) were added to diluted $(1: 3, \mathrm{v} / \mathrm{v})$, strained rumen fluid along with ${ }^{15} \mathrm{NH}_{4} \mathrm{Cl}(\mathrm{A} ; 1.33$ $\mathrm{g} / \mathrm{l})$ and $6.7 \mathrm{~g} / \mathrm{l}$ of a mixture of starch, cellobiose and xylose $(1: 1: 1$, by weight). P and AA, but not $\mathrm{M}$, stimulated net gas production after 4 and $8 \mathrm{~h}$ incubation $(P<0.05)$ in comparison with A alone. $\mathrm{P}$ increased microbial-protein synthesis $(P<0 \cdot 05)$ compared with the other treatments. All of the microbial-N formed after $10 \mathrm{~h}$ was synthesized de novo from ${ }^{15} \mathrm{NH}_{3}$ in treatment $\mathrm{A}$, and the addition of pre-formed amino acids decreased the proportion to $0.37,0.55$, and 0.86 for P, AA, and $\mathrm{M}$ respectively. De novo synthesis of amino acids $(0.29,0.42$ and 0.69 respectively) was lower than cell-N. Enrichment of alanine, glutamate and aspartate was slightly higher than that of other amino acids, while enrichment in proline was much lower, such that $0.83-0.95$ of all proline incorporated into particulate matter was derived from pre-formed proline. Glycine, methionine, lysine, valine and threonine tended to be less enriched than other amino acids. The form in which the amino acids were supplied, as P or AA, had little influence on the pattern of de novo synthesis. When the concentration of peptides was decreased, the proportion of microbial-N formed from $\mathrm{NH}_{3}$ increased, so that at an initial concentration of $1 \mathrm{~g}$ peptides/l, similar to the highest reported ruminal peptide concentrations, 0.68 of cell-N was formed from $\mathrm{NH}_{3}$. Decreasing the $\mathrm{NH}_{3}$ concentration at $1.0 \mathrm{~g}$ peptides/l caused proportionate decreases in the fraction of cell-N derived from $\mathrm{NH}_{3}$, from 0.81 at $0.53 \mathrm{~g} \mathrm{NH}_{3}-\mathrm{N} / 1$ to 0.40 at $0.19 \mathrm{~g} \mathrm{NH}_{3}-\mathrm{N} / \mathrm{l}$. It was concluded that different individual amino acids are synthesized de novo to different extents by mixed rumen micro-organisms when pre-formed amino acids are present, and that the source of $\mathrm{N}$ used for synthesis of cell-N and amino acids depends on the respective concentrations of the different $\mathrm{N}$ sources available; however, supplementing only with amino acids whose synthesis is lowest when pre-formed amino acids are present does not stimulate fermentation or microbial growth.
\end{abstract}

Amino acid: Ammonia: Protein synthesis: Rumen: Sheep

Ammonia has an important role in providing $\mathrm{N}$ for protein synthesis by rumen micro-organisms. Estimates of the contribution of $\mathrm{NH}_{3} v$. preformed amino acids to protein synthesis by the mixed rumen population have been highly variable. ${ }^{15} \mathrm{~N}$ studies using ${ }^{15} \mathrm{NH}_{3}$ or $\left[{ }^{15} \mathrm{~N}\right]$ urea (which rapidly releases $\mathrm{NH}_{3}$ ) infused into the rumen or added as a single dose indicated values of microbial- $\mathrm{N}$ derived from $\mathrm{NH}_{3}$ that ranged from 18 to $100 \%$ (Pilgrim et al. 1970; Al-Rabbat et al. 1971; Mathison \& Milligan, 1971; Nolan, 1975; Nolan et al. 1976; Salter et al. 1979). Incorporation of $\mathrm{NH}_{3}$ was greater in the bacterial fraction (50-78\%) than in protozoa (31-64\%) (Pilgrim et al. 1970; Mathison \& Milligan, 1971). The composition of the diet affects the proportion of microbial protein formed de novo: lucerne hay gave a lower proportional uptake than wheat hay (Pilgrim et al. 1970), and grass hay gave a lower uptake than barley (Mathison \& Milligan, 1971). The dietary factors responsible for these differences between feeds are the availability of readily fermentable energy (Ben-Ghedalia et al. 1978) and the presence of peptides and amino acids (Salter et al. 1979).

Peptides and amino acids stimulate the growth of rumen bacteria (Cotta \& Russell, 1982; Chen et al. 1987b; Cruz

\footnotetext{
* Present address: Departamento de Producción Animal I, Facultad de Veterinaria, Universidad de León, E-24007 León, Spain.

$\dagger$ Corresponding author: Dr R. John Wallace, fax +44 (0)1224 716687, email RJW@RRI.SARI.AC.UK
} 
Soto et al. 1993). Indeed, there may be different responses to peptides compared with amino acids (Argyle \& Baldwin, 1989) depending on the microbial population present (Armstead \& Ling, 1993; Ling \& Armstead, 1995). The efficiency of utilization of peptides and amino acids is very low, however (Cotta \& Russell, 1982), and it would be advantageous to identify whether specific amino acids or groups of amino acids limit the growth of the mixed rumen microbial population. Maeng \& Baldwin (1976), Maeng et al. (1976) and Argyle \& Baldwin (1979) found that only complete mixtures of amino acids gave maximum responses, yet it is clear from other studies that different amino acids are formed de novo to differing extents (Salter et al. 1979). The present study was undertaken to investigate how de novo synthesis of microbial protein and individual amino acids by mixed rumen micro-organisms varied with different $\mathrm{N}$ sources and at different concentrations of $\mathrm{NH}_{3}$ and peptides, and how the rate of fermentation was affected under these circumstances.

\section{Methods}

Animals and diets

Four rumen-fistulated adult sheep received a mixed diet ( $\mathrm{g} /$ $\mathrm{kg}$ ): hay 500, barley 299.5, molasses 100, fishmeal 91, minerals and vitamins 9.5 , fed in equal meals of $500 \mathrm{~g}$ at 08.00 and 16.00 hours. Rumen samples used for measuring gas production and ${ }^{15} \mathrm{NH}_{3}$ incorporation were taken before feeding in the morning from each sheep in order to decrease peptides and amino acids in the inoculum to a minimum. The rumen fluid was kept warm and was strained through linen cloth before use.

\section{Incubations with rumen fluid in vitro}

Gas production. Incubations were carried out using the methods described by Menke \& Steingass (1988). Strained rumen fluid was added under $\mathrm{CO}_{2}$ to a buffer and minerals solution $(1: 2, \mathrm{v} / \mathrm{v})$ at $39^{\circ}$. The buffer and minerals solution contained $(\mathrm{ml} / \mathrm{l})$ : trace elements solution $0 \cdot 12$, buffer 237 , minerals solution $237,1 \mathrm{ml} / 1$ resazurin 1.22 , reducing solution 49.5. The trace elements solution contained $(\mathrm{g} / \mathrm{l}): \mathrm{CaCl}_{2} \cdot 2 \mathrm{H}_{2} \mathrm{O} \quad 132, \mathrm{MnCl}_{2} \cdot 4 \mathrm{H}_{2} \mathrm{O} \quad 100$, $\mathrm{CoCl}_{2} \cdot 6 \mathrm{H}_{2} \mathrm{O} 10, \mathrm{FeCl}_{2} \cdot 6 \mathrm{H}_{2} \mathrm{O}$ 8. The buffer consisted of $(\mathrm{g} / \mathrm{l}): \mathrm{NaHCO}_{3} 35,\left(\mathrm{NH}_{4}\right) \mathrm{HCO}_{3}$ 4. The minerals solution contained (g/l): $\mathrm{Na}_{2} \mathrm{HPO}_{4} 5 \cdot 7, \mathrm{KH}_{2} \mathrm{PO}_{4} 6 \cdot 2, \mathrm{MgSO}_{4} \cdot 7 \mathrm{H}_{2} \mathrm{O}$ $0 \cdot 6$. The reducing solution contained: $5.76 \mathrm{~g} / \mathrm{l} \mathrm{Na}_{2} \mathrm{~S} .7 \mathrm{H}_{2} \mathrm{O}$ and $40.4 \mathrm{ml} 1 \mathrm{M}-\mathrm{NaOH}$. Samples of diluted rumen fluid $(30 \mathrm{ml})$ were then added to $100 \mathrm{ml}$ glass syringes containing energy and $\mathrm{N}$ sources, the syringes were incubated at $39^{\circ}$ and gas volume was measured hourly. The energy source was $200 \mathrm{mg}$ of a mixture of soluble starch, cellobiose and xylose $(1: 1: 1$, by weight). Four different $\mathrm{N}$ sources were used. The added $\mathrm{N}$ sources were $\mathrm{NH}_{4} \mathrm{Cl}(40 \mathrm{mg})$, $\mathrm{NH}_{4} \mathrm{Cl}+$ Trypticase (pancreatic casein hydrolysate; BBL, Becton Dickinson, Cockeysville, MD, USA; $40 \mathrm{mg}$ and $300 \mathrm{mg}$ respectively), $\mathrm{NH}_{4} \mathrm{Cl}+$ casein acid hydrolysate (Oxoid, Basingstoke, Hants., UK, containing added $1.4 \mathrm{~g}$ L-cysteine and $8.68 \mathrm{~g}$ L-tryptophan per $992 \mathrm{~g}$ casein acid hydrolysate; $40 \mathrm{mg}$ and $300 \mathrm{mg}$ respectively), or a mixture of glycine, L-proline, L-valine and L-threonine $(25 \mathrm{mg}$ each).

${ }^{15} \mathrm{~N}$ incorporation. The influence of peptides and amino acids on ${ }^{15} \mathrm{NH}_{3}$ incorporation was investigated using the same samples of rumen fluid in smaller-scale incubations in tubes fitted with Bunsen valves and the same additions of energy and $\mathrm{N}$ sources, except that the $\mathrm{NH}_{4} \mathrm{Cl}$ added to the fermentation mixture was replaced with ${ }^{15} \mathrm{NH}_{4} \mathrm{Cl}(99.6$ atom $\%{ }^{15} \mathrm{~N}$; Europa Scientific, Europa House, Ches., UK). The strained rumen fluid was diluted in the same way as before and the mixtures were incubated under $\mathrm{CO}_{2}$ at $39^{\circ}$. Samples $(5 \mathrm{ml})$ were removed into $5 \mathrm{ml} 100 \mathrm{~g} / \mathrm{l} \mathrm{TCA}$, then were stored at $4^{\circ}$.

A further set of incubations was carried out in which samples of rumen fluid from the same sheep were supplemented with different concentrations of Trypticase, or with less $\mathrm{NH}_{4} \mathrm{Cl}$ while adding $1 \mathrm{~g}$ Trypticase/l. Incubations and sampling were carried out in the same way as before.

\section{${ }^{15} N$ and $N$ analyses}

Pellets from TCA-treated samples were obtained by centrifuging at $28000 \mathrm{~g}$ for $15 \mathrm{~min}$ and washing once with $50 \mathrm{~g} / \mathrm{l}$ TCA. The pellets were freeze-dried, then resuspended in $10 \mathrm{ml} 0.5 \mathrm{M}-\mathrm{NaOH}$ and heated at $100^{\circ}$ for $30 \mathrm{~min} .{ }^{15} \mathrm{~N}$ enrichment was measured by isotope ratio mass spectrometry as described by Barrie \& Workman (1984). N was also measured by a Kjeldahl procedure (Davidson et al. 1970). Freeze-dried pellets were prepared for analysis of ${ }^{15} \mathrm{~N}$ enrichment by hydrolysing in $6 \mathrm{M}-\mathrm{HCl}$ at $115^{\circ}$ overnight. Samples were evaporated at $70^{\circ}$, then resuspended in $2 \mathrm{ml} 0 \cdot 1 \mathrm{M}-\mathrm{HCl}$. The samples were centrifuged again and the supernatant fractions were applied to a Bio-Rad AG 50W-X8 column (Bio-Rad Laboratories Ltd, Hemel Hempstead, Herts., UK) $(1.0 \mathrm{ml})$. The column was washed twice with $2 \mathrm{ml}$ water, then the amino acids were eluted with $2 \mathrm{ml} 2 \mathrm{M}-\mathrm{NH}_{3}$ followed by $1 \mathrm{ml}$ water. The eluted liquid was freeze-dried and stored at $-20^{\circ}$. Tertiary butyldimethysilyl derivatives of the amino acids were prepared and the ${ }^{15} \mathrm{~N}$ enrichment in individual amino acids was determined by GC-mass spectrometry as described by Calder \& Smith (1988). $\mathrm{NH}_{3}$ was measured by the phenol-hypochlorite method adapted from Whitehead et al. (1967). ${ }^{15} \mathrm{~N}$ enrichment in $\mathrm{NH}_{3}$ was determined by incorporating ${ }^{15} \mathrm{NH}_{3}$ into norvaline using glutamate dehydrogenase (EC 1.4.1.2) and 2-oxopentanoate as described by Nieto et al. (1996). The proportion of microbial-N derived from $\mathrm{NH}_{3}$ was calculated as:

$$
2\left(\mathrm{p}_{\mathrm{t}} \mathrm{P}_{\mathrm{t}}-\mathrm{p}_{0} \mathrm{P}_{0}\right) /\left(\mathrm{a}_{\mathrm{t}}+\mathrm{a}_{0}\right)\left(\mathrm{P}_{\mathrm{t}}-\mathrm{P}_{0}\right),
$$

where $\mathrm{a}_{\mathrm{t}}$ is the ${ }^{15} \mathrm{~N}$ enrichment of $\mathrm{NH}_{3}$ at time $\mathrm{t}$ (atom \%), $\mathrm{P}_{\mathrm{t}}$ is the particulate $\mathrm{N}$ concentration at time $\mathrm{t}(\mathrm{g} \mathrm{N} / \mathrm{l})$, and $\mathrm{p}_{\mathrm{t}}$ is the ${ }^{15} \mathrm{~N}$ enrichment of particulate $\mathrm{N}$ at time $\mathrm{t}$ (atom \%). Enrichment in individual amino acids was calculated in the same way.

\section{Statistical analysis}

Values used to calculate the proportion of particulate $\mathrm{N}$ derived from $\mathrm{NH}_{3}$ are given in Table 1 together with the relevant standard deviations. Differences between treatments were compared by an ANOVA table using the Genstat 
computer program (Genstat 5 Committee, 1987, Genstat 5 User's Manual, Oxford University Press, Oxford, Oxon., UK).

\section{Results}

Mixed rumen micro-organisms were incubated anaerobically for $10 \mathrm{~h}$ with a mixture of soluble carbohydrates in the presence of ${ }^{15} \mathrm{NH}_{4} \mathrm{Cl}$ and different added $\mathrm{N}$ sources. Microbial-protein synthesis continued throughout the $10 \mathrm{~h}$ period, as did $\mathrm{NH}_{3}$ production in the Trypticase and amino acids treatments (Fig. 1(a) and (b)). Microbial protein increased more with peptides than with the other treatments, while $\mathrm{NH}_{3}$ production from peptides and amino acids was similar, and higher than from the four amino acids treatment.

The proportion of microbial- $\mathrm{N}$ derived from $\mathrm{NH}_{3}$ during microbial growth was calculated using the average enrichment of ${ }^{15} \mathrm{~N}$ in $\mathrm{NH}_{3}$ over the incubation period and the increase in particulate $\mathrm{N}$ over the same period. $\mathrm{NH}_{3}$ production from Trypticase and amino acids resulted in the ${ }^{15} \mathrm{~N}$ enrichment in $\mathrm{NH}_{3}$ falling substantially (Table 1). The proportion of microbial-N derived from $\mathrm{NH}_{3}$ was 0.37

(a)

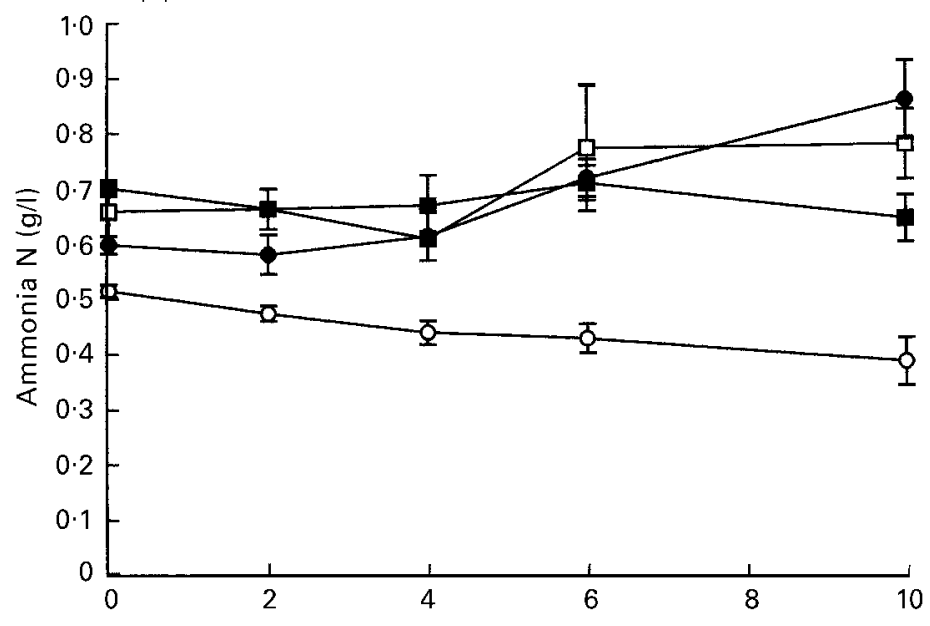

(b)

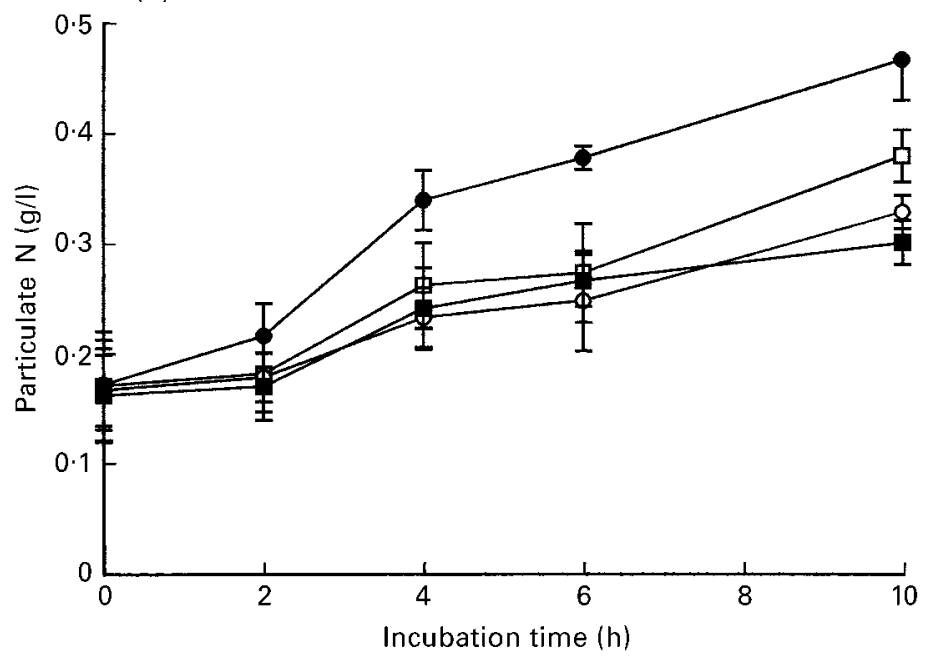

Fig. 1. (a) Ammonia and (b) particulate nitrogen concentrations during the fermentation of a mixture of soluble starch, cellobiose and xylose by mixed micro-organisms from sheep rumen fluid in vitro with different sources of nitrogen. Additions were: $1.33 \mathrm{~g} \mathrm{NH}_{4} \mathrm{Cl} / \mathrm{l}(\mathrm{O}) ; 10 \mathrm{~g}$ Trypticase $+1.33 \mathrm{~g} \mathrm{NH}_{4} \mathrm{Cl} / /(\bullet) ; 10 \mathrm{~g}$ amino acids $+1.33 \mathrm{~g} \mathrm{NH}_{4} \mathrm{Cl} / \mathrm{l}(\square) ; 0.83 \mathrm{~g}$ glycine $+0.83 \mathrm{~g}$ L-proline $+0.83 \mathrm{~g} \mathrm{L-valine}+0.83 \mathrm{~g} \mathrm{L-threonine}+1.33 \mathrm{~g} \mathrm{NH}_{4} \mathrm{Cl} / \mathrm{I}(\boldsymbol{\square})$. Values represent mean values for duplicate incubations of samples of rumen fluid from four sheep, with standard deviations represented by vertical bars. Trypticase, pancreatic casein hydrolysate; BBL, Becton Dickinson, Cockeysville, MD, USA. Amino acids, casein acid hydrolysate (Oxoid, Basingstoke, Hants., UK) $+1.4 \mathrm{~g}$ L-cysteine and $8.68 \mathrm{~g}$ L-tryptophan per $992 \mathrm{~g}$ casein acid hydrolysate. 
with peptides, 0.55 with amino acids, and 0.86 with the four amino acids.

Samples taken at $10 \mathrm{~h}$ were analysed for ${ }^{15} \mathrm{~N}$ enrichment in individual amino acids (Table 2). With the $\mathrm{NH}_{4} \mathrm{Cl}$ treatment, where almost all particulate $\mathrm{N}$ was formed de novo, the enrichment in all amino acids was high, although the enrichment in proline and lysine was slightly lower than the others, indicating some incorporation of preformed amino acids, presumably present in the inoculum. The presence of Trypticase or amino acids decreased de novo synthesis. While incorporation of ${ }^{15} \mathrm{~N}$ into all amino acids was decreased, the effect of Trypticase was greatest with proline, followed by methionine, valine, lysine, and threonine. Free amino acids decreased the de novo synthesis of amino acids to a lesser extent than Trypticase, but the pattern of enrichment in different amino acids was similar, except for lysine and threonine which seemed to be incorporated from Trypticase more effectively than from free amino acids. The most enriched amino acids were glutamate, followed by alanine and aspartate.

When the mixture of proline, valine, threonine and glycine was added to the incubations, de novo synthesis of these amino acids fell markedly. De novo synthesis of all other amino acids except lysine fell as well, notably in leucine and isoleucine (Table 2). The proportion of total amino acids formed de novo (Table 2) was lower than that of total particulate $\mathrm{N}$ (Table 1) in all incubations.

A low rate of gas production occurred in the absence of any addition to the diluted rumen fluid, due to endogenous metabolism, and when Trypticase and amino acids were added to strained rumen fluid in the absence of added energy source, stimulation of gas production occurred via the fermentation of the amino acids to $\mathrm{CO}_{2}$. At each sampling time and for each $\mathrm{N}$ source addition, the net gas production from added carbohydrate (Table 3) was calculated by subtracting gas production in the absence of energy source from total gas production in the presence of energy source. The rate of fermentation of the mixed carbohydrates was increased significantly $(P<0.05)$ by Trypticase and amino acids at 4 and $8 \mathrm{~h}$. The four amino acids treatment did not increase fermentation rate above that found with $\mathrm{NH}_{4} \mathrm{Cl}$ (Table 3).

Similar incubations were carried out in order to determine the influence of altering the concentration of peptides on the incorporation of ${ }^{15} \mathrm{NH}_{3}$ (Table 4). At $1 \mathrm{~g} / \mathrm{l}$ Trypticase (equivalent to $0 \cdot 125 \mathrm{~g} \mathrm{~N} / \mathrm{l}$ ), the amount of cell-N derived from $\mathrm{NH}_{3}$ was $0 \cdot 68$. This value varied above and below $1 \mathrm{~g} / \mathrm{l}$ Trypticase roughly according to $\mathrm{NH}_{3}$ : total soluble $\mathrm{N}$ in the medium. The concentration of peptides remaining at the end of the $8 \mathrm{~h}$ incubation period was not measured, but the extent of peptide breakdown can be assessed by the amounts of $\mathrm{NH}_{3}$ released and microbial-N synthesized. This calculation indicated that less than half of the Trypticase was broken down after $8 \mathrm{~h}$ incubation at an initial concentration of $5 \mathrm{~g} / \mathrm{l}$. At lower concentrations, all of the Trypticase would be expected to be incorporated or broken down to $\mathrm{NH}_{3}$ or incorporated into microbial cells after $8 \mathrm{~h}$ (Table 4).

A similar experiment was carried out in which the concentration of $\mathrm{NH}_{3}$ was varied, while maintaining an initial concentration of $1 \mathrm{~g}$ Trypticase/l (Table 5). The fraction of cell-N derived from $\mathrm{NH}_{3}$ fell as the concentration decreased, again roughly in proportion to $\mathrm{NH}_{3}$ : total soluble 
Table 2. Influence of different nitrogen sources on $\left[{ }^{15} \mathrm{~N}\right]$ ammonia incorporation into individual amino acids by mixed micro-organisms from sheep rumen fluid fermenting a mixture of soluble starch, cellobiose and xylose

(Mean values for duplicate $10 \mathrm{~h}$ incubations of rumen fluid from four sheep)

\begin{tabular}{|c|c|c|c|c|c|c|}
\hline \multirow[b]{2}{*}{$\mathrm{N}$ source $† \ldots$} & \multicolumn{4}{|c|}{ Proportion of new amino acid- $\mathrm{N}$ formed which was derived from ${ }^{15} \mathrm{NH}_{3}$} & \multirow[b]{2}{*}{ SED } & \multirow{2}{*}{$\begin{array}{c}\text { Statistical significance of } \\
\text { difference between means } \\
\text { (ANOVA) }: \therefore P\end{array}$} \\
\hline & $\mathrm{NH}_{4} \mathrm{Cl}$ & Trypticaseł & Amino acids§ & Gly+Val+Pro+Thr & & \\
\hline Ala & 1.06 & 0.50 & 0.68 & 1.04 & 0.074 & 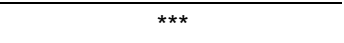 \\
\hline Gly & 0.93 & 0.29 & 0.39 & 0.31 & 0.032 & $* * *$ \\
\hline Val & 0.97 & 0.22 & 0.31 & 0.49 & 0.039 & $* * *$ \\
\hline Leu & 0.90 & 0.27 & 0.33 & 0.69 & 0.045 & $* * *$ \\
\hline Ile & 0.90 & 0.27 & 0.37 & 0.68 & 0.042 & $* * *$ \\
\hline Pro & 0.79 & 0.06 & 0.09 & 0.20 & 0.020 & $\star * \star$ \\
\hline Ser & 0.92 & 0.33 & 0.47 & 0.77 & 0.046 & $* \star *$ \\
\hline Thr & 0.92 & 0.24 & 0.38 & 0.50 & 0.034 & $* * *$ \\
\hline Met & 0.92 & 0.16 & 0.24 & 0.84 & 0.052 & 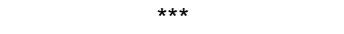 \\
\hline Phe & 0.87 & 0.34 & 0.41 & 0.80 & 0.046 & $* \star *$ \\
\hline Asp & 0.89 & 0.40 & 0.63 & 0.84 & 0.051 & $* * *$ \\
\hline Glu & 0.92 & 0.42 & 0.66 & 0.88 & 0.056 & $* * *$ \\
\hline Lys & 0.74 & 0.23 & 0.42 & 0.79 & 0.043 & $* * *$ \\
\hline Tyr & 0.90 & 0.32 & 0.43 & 0.84 & 0.050 & $* * *$ \\
\hline Mean & 0.90 & 0.29 & 0.42 & 0.69 & 0.042 & $* * *$ \\
\hline
\end{tabular}

*** $P<0.001$.

†For $\mathrm{N}$ concentration in each $\mathrm{N}$ source, see Table 1.

$\ddagger$ Pancreatic casein hydrolysate; BBL, Becton Dickinson, Cockeysville, MD, USA.

$\S$ Casein acid hydrolysate (Oxoid, Basingstoke, Hants., UK) with $1.4 \mathrm{~g}$ L-cysteine and $8.68 \mathrm{~g} \mathrm{L-tryptophan} \mathrm{added} \mathrm{per} 992 \mathrm{~g}$ casein acid hydrolysate.

$\mathrm{N}$ in the medium. Particulate- $\mathrm{N}$ production fell at the highest $\mathrm{NH}_{3}$ concentration $\left(0.35 \mathrm{~g} \mathrm{NH}_{3}-\mathrm{N} / \mathrm{l}\right)$, but because no sugar estimations were done it is not clear if this was caused by decreased growth yield or growth rate.

\section{Discussion}

The present experiments were undertaken to determine the influence of pre-formed amino acids on the de novo synthesis of different amino acids and the influence of the nature of these amino acids (whether free or in the form of peptides) and their concentration on de novo synthesis of cell-N and amino acids. Batch incubations were used,

Table 3. Influence of nitrogen source on fermentation rate of mixed rumen micro-organisms in vitro

(Mean values for duplicate incubations of rumen fluid from four sheep)

\begin{tabular}{|c|c|c|c|}
\hline \multirow[b]{2}{*}{ Incubation time... } & \multicolumn{3}{|c|}{ Net gas production (ml) } \\
\hline & $4 \mathrm{~h}$ & $8 \mathrm{~h}$ & $12 \mathrm{~h}$ \\
\hline \multicolumn{4}{|l|}{ Treatment } \\
\hline $\mathrm{NH}_{4} \mathrm{Cl}$ & $15 \cdot 9$ & 43.4 & $57 \cdot 0$ \\
\hline Trypticaseł & $19 \cdot 4$ & $47 \cdot 0$ & 59.5 \\
\hline Amino acids§ & $17 \cdot 6$ & $46 \cdot 7$ & $59 \cdot 4$ \\
\hline Gly + Pro + Val + Thr & $15 \cdot 1$ & 41.2 & 57.9 \\
\hline SED & 1.35 & 1.70 & $2 \cdot 14$ \\
\hline $\begin{array}{l}\text { Statistical significance of difference } \\
\text { between means (ANOVA): } P\end{array}$ & * & * & \\
\hline
\end{tabular}

${ }^{*} P<0.05$.

†For $\mathrm{N}$ concentrations in each $\mathrm{N}$ source, see Table 1.

$\ddagger$ Pancreatic casein hydrolysate; BBL, Becton Dickinson, Cockeysville, MD, USA.

§Casein acid hydrolysate (Oxoid, Basingstoke, Hants., UK) with $1.4 \mathrm{~g} \mathrm{L-}$ cysteine and $8.68 \mathrm{~g}$ L-tryptophan added per $992 \mathrm{~g}$ casein acid hydrolysate. supplemented with a mixture of soluble starch, cellobiose and xylose. Thus the micro-organisms whose growth would be supported most would be those fermenting non-structural carbohydrates (Russell et al. 1992). Many of the calculations are based on average values obtained from 8 or $10 \mathrm{~h}$ incubations. Although some error is introduced by this approximation, such as when initial peptide concentrations were low and peptides would have been depleted during the incubation (Table 4), the patterns of $\mathrm{NH}_{3}$ concentration and microbial-protein synthesis (Fig. 1) suggest that the fermentation was continuous over this period and the assumption is not greatly in error in most cases.

It is well known that rumen micro-organisms, as a population, have no absolute requirement for amino acids (Virtanen, 1966; Salter et al. 1979). The present data, from incubations with no added amino acids, provide confirmation of these findings. Most rumen bacteria have simple $\mathrm{N}$ requirements and can synthesize the majority of their amino acids from $\mathrm{NH}_{3}$, via glutamate dehydrogenase (EC 1.4.1.2) or alanine dehydrogenase (EC 1.4.1.1) (Wallace et al. 1997), particularly if C skeletons are available (Allison \& Bryant, 1963; Allison, 1969, 1970). Even those bacteria requiring some amino acids can probably, in the mixed population, scavenge amino acids released by the breakdown of protein by other species.

The extent to which rumen micro-organisms actually use their capability for de novo amino acid synthesis is of more relevance to practical feeding conditions. The results presented here demonstrate that the proportion of cell-N formed from $\mathrm{NH}_{3}$ is not fixed, but varies approximately according to $\mathrm{NH}_{3}-\mathrm{N}$ : total $\mathrm{N}$ available for growth. Thus, because this ratio varies between diets and throughout the day on any single diet if animals are meal-fed (Chalmers \& Synge, 1954; Chen et al. 1987a,b; Broderick \& Wallace, 1988; Wallace \& McKain, 1990; Williams \& Cockburn, 
Table 4. Influence of different concentrations of Trypticase $†$ on $\left[{ }^{15} \mathrm{~N}\right]$ ammonia incorporation by mixed micro-organisms from sheep rumen fluid fermenting a mixture of soluble starch, cellobiose and xylose

(Mean values for triplicate $8 \mathrm{~h}$ incubations of rumen fluid from three sheep)

\begin{tabular}{|c|c|c|c|c|c|c|c|c|}
\hline & \multicolumn{6}{|c|}{ Concentration of Trypticase (g N/l) } & SED & $\begin{array}{c}\text { Statistical significance of } \\
\text { difference between means } \\
\text { (ANOVA) :P }\end{array}$ \\
\hline $\begin{array}{l}\text { Proportion of cell-N derived from }{ }^{15} \mathrm{NH}_{3} \\
\mathrm{NH}_{3} \text { concentration }(\mathrm{g} \mathrm{N} / \mathrm{l})\end{array}$ & $1 \cdot 14$ & 0.96 & $0 \cdot 80$ & 0.68 & 0.53 & 0.37 & 0.066 & $* * *$ \\
\hline Initial & 0.536 & 0.562 & 0.560 & 0.570 & 0.572 & 0.599 & 0.012 & \\
\hline Final & 0.429 & 0.448 & 0.487 & 0.543 & 0.683 & 0.862 & 0.019 & $* \star *$ \\
\hline Mean $\mathrm{NH}_{3}-\mathrm{N}$ : total soluble $\mathrm{N}$ & 1.00 & 0.97 & 0.89 & 0.81 & 0.50 & 0.37 & & \\
\hline $\begin{array}{l}\mathrm{N} \text { formed from sources other } \\
\text { than } \mathrm{NH}_{3}(\mathrm{~g} / \mathrm{l})\end{array}$ & 0.018 & 0.032 & 0.092 & 0.143 & 0.280 & 0.557 & 0.013 & *** \\
\hline
\end{tabular}

*** $P<0.001$.

†Pancreatic casein hydrolysate; BBL, Becton Dickinson, Cockeysville, MD, USA.

$\ddagger$ Data reproduced from Table 1 (duplicate $10 \mathrm{~h}$ incubations of rumen fluid from four sheep).

Table 5. Influence of different concentrations of ammonia on $\left[{ }^{15} \mathrm{~N}\right]$ ammonia incorporation by mixed micro-organisms from sheep rumen fluid fermenting a mixture of soluble starch, cellobiose and xylose and $1 \mathrm{~g}$ Trypticase/l $\dagger$

(Mean values for triplicate $8 \mathrm{~h}$ incubations of rumen fluid from four sheep)

\begin{tabular}{|c|c|c|c|c|c|c|}
\hline & \multicolumn{4}{|c|}{ Concentration of $\mathrm{NH}_{3}$ added ( $\left.\mathrm{g} \mathrm{N} / \mathrm{l}\right)$} & SED & $\begin{array}{c}\text { Statistical significance of } \\
\text { difference between means } \\
\text { (ANOVA) }: P\end{array}$ \\
\hline $\begin{array}{l}\text { Proportion of cell-N derived from }{ }^{15} \mathrm{NH}_{3} \\
\mathrm{NH}_{3} \text { concentration }(\mathrm{g} \mathrm{N} / \mathrm{l})\end{array}$ & 0.40 & 0.52 & $0 \cdot 72$ & 0.81 & 0.062 & $* * *$ \\
\hline Initial & 0.191 & 0.247 & 0.381 & 0.533 & 0.010 & $* * *$ \\
\hline Final & 0.142 & 0.190 & 0.330 & 0.483 & 0.008 & $* * *$ \\
\hline Mean $\mathrm{NH}_{3}-\mathrm{N}$ : total soluble $\mathrm{N}$ & 0.56 & 0.63 & 0.73 & 0.80 & & \\
\hline Particulate $\mathrm{N}$ produced $(\mathrm{g} / \mathrm{l})$ & 0.120 & $0 \cdot 131$ & 0.124 & 0.125 & 0.005 & \\
\hline
\end{tabular}

*** $P<0.001$.

†Pancreatic casein hydrolysate; BBL, Becton Dickinson, Cockeysville, MD, USA.

1991), the proportion of cell- $\mathrm{N}$ formed from $\mathrm{NH}_{3}$ will also vary widely. This factor alone may account for the wide variation in values found in in vivo studies (see p. 307). The constant proportion of 0.34 assumed by Russell et al. (1992) when both peptides and $\mathrm{NH}_{3}$ are available (based on in vitro mixed cultures with casein and mixed soluble carbohydrates carried out by Russell et al. 1983) may have to be varied to account for different diets. A wider range of conditions will have to be investigated to determine the precise way in which variation occurs.

Another issue is whether preformed amino acids are beneficial to the rate of fermentation or to growth yield. These questions have been dealt with in detail elsewhere (Maeng \& Baldwin, 1976; Maeng et al. 1976; Argyle \& Baldwin, 1979; Russell et al. 1983, 1992; Cruz Soto et al. 1993; Chikunya et al. 1996). Here, peptides and amino acids supported an increased fermentation rate (Table 3) and growth yield (Tables 1 and 4), consistent with proposed effects of peptides on non-cellulolytic rumen bacteria (Russell et al. 1992; Chikunya et al. 1996).

The incorporation of $\mathrm{NH}_{3}$ into amino acids was lower than incorporation into total cell-N, presumably reflecting the different precursors of nucleic acids and peptidoglycan biosynthesis compared with protein. All amino acids and peptides treatments caused similar differences between the proportions of total cell- $\mathrm{N}$ and amino acid-N derived from
$\mathrm{NH}_{3}$. The amino acids were enriched to very different extents when pre-formed amino acids were available. Glutamate and alanine, followed by aspartate, were always synthesized to a greater extent than other amino acids and their synthesis was suppressed least by the addition of Trypticase or amino acids, reflecting the role of these amino acids in the early reactions of $\mathrm{NH}_{3}$ assimilation (Chalupa et al. 1970; Erfle et al. 1977; Blake et al. 1983; Wallace et al. 1997). Exactly how the $\mathrm{NH}_{3}$ becomes incorporated in the first instance remains unclear, however. Amides were not measured here, but in view of the evident importance of amides in the initial phase of $\mathrm{NH}_{3}$ trapping (Salter et al. 1979), part of the regulation may occur at the level of amide synthesis. The best known microbial enzyme system for $\mathrm{NH}_{3}$ assimilation via amide- $\mathrm{N}$ is the glutamine synthetase (EC 6.3.1.2)-glutamate synthase (EC 1.4.7.1) (GS-GOGAT) couple (Brown et al. 1974). GOGAT has been demonstrated to be present in rumen micro-organisms, but only under conditions of low $\mathrm{NH}_{3}$ concentrations (Erfle et al. 1977).

The synthesis of glutamate and alanine decreased by $28-$ $54 \%$ in the presence of Trypticase and amino acids, while de novo synthesis of some amino acids was inhibited by more than $80 \%$. Proline synthesis was particularly subject to suppression, and glycine, valine, leucine and threonine synthesis were also suppressed more than others. Why 
proline biosynthesis should be so sensitive to pre-formed proline when other amino acids were affected less is not clear. ${ }^{15} \mathrm{~N}$ abundance was also low in proline in the experiments of Salter et al. (1979), although not to the same extent as found here.

The suppression of de novo synthesis of different amino acids followed a fairly similar pattern with the different additions. It was therefore considered possible that proline could be most stimulatory to the mixed fermentation, so proline was one of the four amino acids added to the mixed fermentation in order to determine if adding the amino acids which rumen micro-organisms tend to avoid synthesizing could alter the overall incorporation pattern of ${ }^{15} \mathrm{NH}_{3}$ or change the rate of fermentation. The four amino acids did not stimulate the rate of fermentation. The de novo synthesis of the four amino acids was, not unexpectedly, greatly decreased. The finding that an incomplete mixture of amino acids fails to support growth in the same way as a complete mixture is similar to the findings of others (Maeng et al. 1976; Argyle \& Baldwin, 1979). It would be possible to add other individual amino acids to determine their influence on fermentation rate (e.g. lysine is an example of an amino acid which is synthesized less than others when pre-formed amino acids are available) but the indications from the other studies are that a response is improbable.

\section{Implications}

The finding that $\mathrm{NH}_{3}$ and peptide uptake by rumen microorganisms is only loosely regulated is surprising, particularly in view of the evident regulation of synthesis of some individual amino acids, notably proline. A similar pattern was found in pure cultures of non-cellulolytic rumen bacteria (Atasoglu et al. 1998). One might have expected a more closely regulated switch mechanism than actually occurs, where the $\mathrm{N}$ source used for growth appears to depend to a large extent on the relative quantities of each that are available. Future research should investigate the implications of these findings for growth rates and yields, and nutritional strategies should recognize that, for example, the provision of non-protein- $\mathrm{N}$ as a supplement may suppress the incorporation of amino acids from true protein in the feed.

\section{Acknowledgements}

We thank the British Council for their support under the Acciones Integradas scheme. The analytical skills of Maureen Annand, David Brown, Graham Calder and Eric Milne are gratefully acknowledged.

\section{References}

Allison MJ (1969) Biosynthesis of amino acids by ruminal microorganisms. Journal of Animal Science 29, 797-807.

Allison MJ (1970) Nitrogen metabolism of ruminal microorganisms. In Physiology of Digestion and Metabolism in the Ruminant, pp. 456-473 [AT Phillipson, editor]. Newcastle: Oriel Press Ltd.

Allison MJ \& Bryant MP (1963) Biosynthesis of branched-chain amino acids from branched-chain fatty acids by rumen bacteria. Archives of Biochemistry and Biophysics 101, 269-277.

Al-Rabbat MF, Baldwin RL \& Weir WC (1971) Microbial growth dependence on ammonia nitrogen in the bovine rumen: a quantitative study. Journal of Dairy Science 54, 1162-1172.

Argyle JL \& Baldwin RL (1989) Effects of amino acids and peptides on rumen microbial growth yields. Journal of Dairy Science 72, 2017-2027.

Armstead IP \& Ling JR (1993) Variations in the uptake and metabolism of peptides and amino acids by mixed ruminal bacteria in vitro. Applied and Environmental Microbiology 59, 3360-3366.

Atasoglu C, Valdés C, Walker ND, Newbold CJ \& Wallace RJ (1998) De novo synthesis of amino acids by the ruminal bacteria Prevotella bryantii $\mathrm{B}_{1} 4$, Selenomonas ruminantium HD4, and Streptococcus bovis ES1. Applied and Environmental Microbiology 64, 2836-2843.

Barrie S \& Workman CT (1984) An automated analytical system for nutritional investigations using N-15 tracers. Spectroscopy International Journal 3, 439-447.

Ben-Ghedalia D, McMeniman NP \& Armstrong DG (1978) The effect of partially replacing urea nitrogen with protein $\mathrm{N}$ on $\mathrm{N}$ capture in the rumen of sheep fed a purified diet. British Journal of Nutrition 39, 37-44.

Blake JS, Salter DN \& Smith RH (1983) Incorporation of nitrogen into rumen bacterial fractions of steers given protein- and urea-containing diets. Ammonia assimilation into intracellular bacterial amino acids. British Journal of Nutrition 50, 769782.

Broderick GA \& Wallace RJ (1988) Effects of dietary nitrogen source on concentrations of ammonia, free amino acids and fluorescamine-reactive peptides in the sheep rumen. Journal of Animal Science 66, 2233-2238.

Brown CM, MacDonald-Brown DS \& Meers JL (1974) Physiological aspects of microbial inorganic nitrogen metabolism. Advances in Microbial Physiology 11, 1-52.

Calder AG \& Smith A (1988) Stable isotope ratio analysis of leucine and ketoisocaproic acid in blood plasma by gas chromatography/mass spectrometry. Use of tertiary butyldimethylsilyl derivatives. Rapid Communications in Mass Spectrometry 2, 14-16.

Chalmers MI \& Synge RLM (1954) The digestion of protein and nitrogenous compounds in ruminants. Advances in Protein Chemistry 9, 93-120.

Chalupa W, Clark J, Opliger P \& Lavker R (1970) Ammonia metabolism in rumen bacteria and mucosa from sheep fed soy protein or urea. Journal of Nutrition 100, 161-169.

Chen G, Sniffen CJ \& Russell JB (1987a) Concentration and estimated flow of peptides from the rumen of dairy cattle: effects of protein quantity, protein solubility and feeding frequency. Journal of Dairy Science 70, 983-992.

Chen G, Strobel HJ, Russell JB \& Sniffen CJ (1987b) Effect of hydrophobicity on utilization of peptides by ruminal bacteria in vitro. Applied and Environmental Microbiology 53, 2021-2025.

Chikunya S, Newbold CJ, Rode L, Chen XB \& Wallace RJ (1996) Influence of dietary rumen-degradable protein on bacterial growth in the rumen of sheep receiving different energy sources. Animal Feed Science and Technology 63, 333-340.

Cotta MA \& Russell JB (1982) Effect of peptides and amino acids on efficiency of rumen bacterial protein synthesis in continuous culture. Journal of Dairy Science 65, 226-234.

Cruz Soto R, Muhammed SA, Newbold CJ, Stewart CS \& Wallace RJ (1993) Influence of peptides, amino acids and urea on microbial activity in the rumen of sheep receiving grass hay and on the growth of rumen bacteria in vitro. Animal Feed Science and Technology 49, 151-161.

Davidson J, Mathieson J \& Boyne AW (1970) The use of 
automation in determining nitrogen by the Kjeldahl method, with final calculation by computer. Analyst 95, 181-193.

Erfle JD, Sauer FD \& Mahadevan S (1977) Effect of ammonia concentration on activity of enzymes of ammonia assimilation and on synthesis of amino acids by mixed rumen bacteria in continuous culture. Journal of Dairy Science 60, 1064-1072.

Ling JR \& Armstead IP (1995) The in vitro uptake and metabolism of peptides and amino acids by five species of rumen bacteria. Journal of Applied Bacteriology 78, 116-124.

Maeng WJ \& Baldwin RL (1976) Factors influencing rumen microbial growth rates and yields: effect of amino acid additions to a purified diet with nitrogen from urea. Journal of Dairy Science 59, 648-655.

Maeng WJ, Van Nevel CJ, Baldwin RL \& Morris JG (1976) Rumen microbial growth rates and yields: effect of amino acids and protein. Journal of Dairy Science 59, 68-79.

Mathison GW \& Milligan LP (1971) Nitrogen metabolism in sheep. British Journal of Nutrition 25, 351-366.

Menke KH \& Steingass H (1988) Estimation of the energetic feed value obtained from chemical analysis and in vitro gas production using rumen fluid. Animal Research and Development 28, $8-55$.

Nieto R, Calder AG, Anderson SE \& Lobley GE (1996) Method for the determination of ${ }^{15} \mathrm{NH}_{3}$ enrichment in biological samples by gas chromatography/electron impact mass spectrometry. Journal of Mass Spectrometry 31, 289-294.

Nolan J (1975) Quantitative models of nitrogen metabolism in sheep. In Digestion and Metabolism in the Ruminant, pp. 416431 [IW McDonald and ACI Warner, editors]. Armidale, NSW, Australia: University of New England Publishing Unit.

Nolan JV, Norton BW \& Leng RA (1976) Further studies on the dynamics of nitrogen metabolism in sheep. British Journal of Nutrition 35, 127-147.
Pilgrim AF, Gray FV, Weller RA \& Belling GB (1970) Synthesis of microbial protein from ammonia in the sheep's rumen and the proportion of dietary nitrogen converted into microbial $\mathrm{N}$. British Journal of Nutrition 24, 589-598.

Russell JB, O'Connor JD, Fox DG, Van Soest PJ \& Sniffen CJ (1992) A net carbohydrate and protein system for evaluating cattle diets. 1. Ruminal fermentation. Journal of Animal Science 70, 3551-3561.

Russell JB, Sniffen CJ \& Van Soest PJ (1983) Effect of carbohydrate limitation on degradation and utilization of casein by mixed rumen bacteria. Journal of Dairy Science 66, 763-775.

Salter DN, Daneshvar K \& Smith RH (1979) The origin of nitrogen incorporated into compounds in the rumen bacteria of steers given protein- and urea-containing diets. British Journal of Nutrition 41, 197-209.

Virtanen AI (1966) Milk production of cows on protein-free feed. Science 153, 1603-1614.

Wallace RJ \& McKain N (1990) A comparison of methods for determining the concentration of extracellular peptides in rumen fluid of sheep. Journal of Agricultural Science, Cambridge 114, 101-105.

Wallace RJ, Onodera R \& Cotta MA (1997) Metabolism of nitrogen-containing compounds. In The Rumen Microbial Ecosystem, pp. 283-328 [PN Hobson and CS Stewart, editors]. London: Chapman \& Hall.

Whitehead R, Cooke GH \& Chapman BT (1967) Problems associated with the continuous monitoring of ammoniacal nitrogen in river water. Automation in Analytical Chemistry 2, 377380 .

Williams AP \& Cockburn JE (1991) Effect of slowly and rapidly degraded protein sources on the concentration of amino acids and peptides in the rumen of steers. Journal of the Science of Food and Agriculture 56, 303-314. 